\title{
THE MALAYSian FEDERAL CONSTITUTION: AN ISLAMIC OR a SECUlar CoNSTITUTION?
}

\author{
Syed Fadhil Hanafi Syed A. Rahman* \\ Bank Negara Malaysia \\ syfadh@bnm.gov.my
}

\begin{abstract}
Constitutionalism dictates that the government must only act within the four walls of the constitution. While adherence to this fundamental doctrine is proven to be difficult, it becomes more complicated when the walls are unclear. For decades, Malaysians struggle to ascertain the actual legal value of religion, particularly Islam, in its Federal Constitution and the impact of religion to the Malaysian legal system. Some opined that secularism is a basic structure of the Malaysian Federal Constitution and in the name of constitutionalism, religious laws cannot be the basis for administration of public law and must be confined to personal law matters. On the other hand, some opined that Islam constitutes a salient feature of the Constitution and the position of Islam as the religion of the Federation implies Malaysia as an Islamic state. This paper analyses the conflicting views, via qualitative studies of constitutional provisions which have religious element in the light of their history, together with relevant case laws which interpreted them. The analysis is done with a view to determine whether the Malaysian Federal Constitution is a secular instrument creating a secular state or a religious document establishing a theocratic state. From such analysis, the author presents that the Malaysian Federal Constitution, albeit giving special preference to Islam, is a religion-neutral document which is receptive to both religious and secular laws. This is based on the fact that the Constitution upholds the validity of both secular and religious laws for as long as they are enacted according to procedural laws required by the Constitution.
\end{abstract}

Keywords: Malaysian Federal Constitution, secularism, doctrine of basic structure, secular state, theocratic state.

* Senior Legal Counsel at Legal Department, Bank Negara Malaysia and also Syarie Lawyer of Federal Territories, Malaysia. This article represents the author's personal views. 


\section{INTRODUCTION}

Constitutionalism is the most potent arsenal of modern democratic states against abuse of power by the government. The mere existence of a constitution is pointless if people do not strive towards adherence. Before we start discussing about adherence to constitution, there must be some degree of clarity as to what are the constitutional boundaries which the government cannot surpass.

In Malaysia, constitutional walls that define the legal status and impact of religion in the Malaysian Federal Constitution (MFC) continue to be a subject matter of speculation. This uncertainty has adverse effect to the stability of multi-religious and culturally-diverse society in Malaysia especially when it is exploited as political tools to instil fear and cause tension within certain segment of the society. Further, the same uncertainty has hindered the development of the Malaysian legal system especially the adoption of religious laws into the Malaysian public law sphere.

Such problem is mainly due to the absence of a decisive constitutional provision and case law on this issue. Although Article 3 of the MFC unequivocally declared Islam as the religion of the Federation, its actual meaning and effect remain highly disputed. Even the court has given mixed decisions on this matter. The difference of opinions is closely related to the hudud and Islamic state debates as well as the proposed amendments to the Syariah Courts (Criminal Jurisdiction) Act 1965 [Act 355] to expand Syariah Court's jurisdiction in punishing offences against the precepts of Islam. Pro-secular group in Malaysia argued, among others, that secularism is a basic structure of the MFC and adoption of religious law into the public law sphere offends its secular nature and unconstitutional. On the contrary, pro-Syariah group argued that nothing in the MFC prohibits the implementation of Islamic criminal law in Malaysia.

It is critical, in the author's view, for this issue to be carefully studied and addressed because the pro-secular group's contention presents huge impacts to the Malaysian legal system and the position of Islam in the MFC. If secularism is taken as a basic structure of the MFC: 
(a) the MFC must be interpreted based on secular approach and Islamic principles which are not in line with secular values will be ignored;

(b) Islamic criminal law can never be implemented in Malaysia even via amendment to the MFC because the parliament does not have the power to amend a basic structure of the MFC;

(c) notwithstanding Islam as the religion of the Federation, Islam shall remain for ritual and ceremonial purposes only and does not have special status but rank equally with other religions in Malaysia; and

(d) laws relating to Islam enacted by state legislative assemblies (SLA) particularly relating to offences against the precepts of Islam are very likely to be declared unconstitutional.

Premised on the above, the objective of this article is to determine whether the MFC is a secular instrument creating a secular state or a religious document establishing a theocratic state. The methodology adopted is qualitative studies of the text of the MFC, particularly provisions which have religious element in the light of historical documents on which they were inserted and cases decided by the Malaysian superior courts which interpreted those provisions. In addition, the author also analysed relevant case laws decided by foreign courts as well as views on secularism and the doctrine of basic structure of constitution.

\section{THE ISLAMIC STATE AND HUDUD DEBATES}

The debate on whether Malaysia is an Islamic or a secular state could be said to have been intensified by the declaration made by the Fourth Prime Minister, Dr. Mahathir Mohamad on 29 September 2001, during his opening address at the Gerakan Party's $30^{\text {th }}$ National Delegates Conference where he announced:

UMNO wishes to state loudly that Malaysia is an Islamic country. This is based on the opinion of ulamaks who had clarified what constituted as Islamic country. If Malaysia is not an Islamic country because it does not implement the hudud, then there are no Islamic countries in the world. If UMNO says that Malaysia is an Islamic country, it is because in an Islamic country non-Muslims have specific rights. This is in line with the teachings of Islam. There is no compulsion in Islam. And Islam does not like chaos that may come about if Islamic laws are enforced on non-Muslims. ${ }^{1}$

Tommy Thomas, "Is Malaysia an Islamic state?" Malayan Law Journal, no. 4 (2006): xv. 
The controversial declaration was followed by another stronger statement in the parliament on 17 June 2002 that Malaysia is not a moderate Islamic State but a fundamentalist Islamic State. ${ }^{2}$

Since then, the issue became a national debate. Some agreed with Mahathir's declaration while some others heavily criticized him, among others, for contradicting the words of his predecessors, the First Prime Minister and the Father of Independence, Tunku Abdul Rahman ${ }^{3}$ and the Third Prime Minister, Tun Hussein Onn who rejected the idea of Malaysia being an Islamic state. ${ }^{4}$ Even Parti Islam Se-Malaysia (PAS), the political party that promotes the implementation of hudud (which the author believes is more accurately referred to as Islamic criminal law because hudud is only one component of Islamic criminal law) in Malaysia, also refused to accept the declaration but not on the basis that the MFC is secular but because Malaysia does not implement Islamic criminal law. ${ }^{5}$

Although this article is neither about whether Malaysia is an Islamic state nor whether Islamic criminal law can be implemented in Malaysia, these debates are relevant because the primary contention of the opponents of Mahathir's declaration and PAS's proposal to implement Islamic criminal law in Malaysia is that they are inconsistent with the MFC which is purportedly secular in nature making Malaysia a secular state despite Article 3 that explicitly provides Islam as the religion of the Federation.

The most often quoted authority to justify secular nature of the MFC is the decision of the Supreme Court in 1988 delivered by the Lord President, Salleh Abas in Che Omar Bin Che Soh v Public Prosecutor. ${ }^{6}$ His lordship rejected the defendant's argument that the death penalty for drug trafficking

\footnotetext{
"Mahathir: Malaysia is 'Fundamentalist State," CNN.com/World, June 18, 2002, http://edition.cnn.com/2002/ WORLD/asiapcf/southeast/06/18/malaysia.mahathir/.

3 Tunku Abdul Rahman, is reported to have said in the Dewan Rakyat (Hansard, 1 May 1958) that "I would like to make it clear that this country is not an Islamic State as it is generally understood, we merely provided that Islam shall be the official religion of the State."

4 "MCCBCHST's Press Statement: Malaysia is Not an Islamic State," The Malaysian Bar, accessed April 21, 2019, http://www.malaysianbar.org.my/letters_others/mccbchsts_press_statement_malaysia_is_not_an_islamic_state. html.

5 Thomas, "Is Malaysia an Islamic state?" xv.

6 Che Omar bin Che Soh v. Public Prosecutor (2) (1988), The Malayan Law Journal 55.
} 
and firearm offences was unconstitutional for being contrary to Islam. While upholding the validity of death penalty for the said offences, the Supreme Court remarked that there is no provision in the MFC which nullifies any law contrary to the injunction of Islam and instead, Article 162 of the MFC preserves the continuity of secular law prior to the MFC. Relying on the said judgement, the pro-secular group maintains that Article 3 of the MFC is only meant for rituals and ceremonies only and was not intended to derogate the secular nature of the MFC. ${ }^{7}$

Additionally, the pro-secular group argued that preparatory works of the MFC stated, with regards to the issue of the state's religion, that insertion of provision on state's religion did not in any way imply that Malaysia is not a secular state. Among the advocates of this idea are the former President of the Democratic Action Party (DAP), the late Karpal Singh, ${ }^{8}$ DAP leader, Lim Kit Siang,9 former presidents of the Malaysian Bar, Ragunath Kesavan, ${ }^{10}$ Mah Weng Kwai ${ }^{11}$ and Steven Thiru, ${ }^{12}$ and the current Attorney General of Malaysia, Tommy Thomas. ${ }^{13}$

On the other hand, the current President of the Malaysian Muslim Lawyers Association, Zainul Rijal Abu Bakar disagreed with Steven Thiru's statement and stated that the statement itself is unconstitutional because "nowhere also does the Constitution envisage [Malaysia as] a complete secular State" and the stance was based on a wrongful reading of the decision in Che Omar's

7 Thomas, "Is Malaysia an Islamic state?" xv.

8 "Hudud Law Incompatible with Secular State, Says Karpal," The Rocket, accessed April 21, 2019, https://www. therocket.com.my/en/implementation-of-hudud-in-kelantan-is-ill-advised-says-karpal/.

9 "DAP CEC will Consider Proposal to Take Mahathir to Court for His "929 Declaration" and His "617 Announcement" that Malaysia is an Islamic Fundamentalist State," limkitsiang.com, accessed April 21, 2019, http:// www.limkitsiang.com/archive/2002/juno2/lks1658.htm.

10 Hariati Azizan," "Secular in Spirit," The Star Online, April 2, 2017, https://www.thestar.com.my/news/nation/2017/04/02/secular-in-spirit-we-need-to-look-at-our-shared-past-namely-the-founding-principle-of-thecountry-an/.

11 Lee Ban Chen, "The Islamic State Debacle," Malaysiakini, November 11, 2001, http://www.malaysiakini.com/ columns/7017.

12 "Hudud is Unconstitutional, Discriminatory and Divisive," The Malaysian Bar, accessed April 21, 2019, http://www. malaysianbar.org.my/press_statements/press_release_\%7C_hudud_is_unconstitutional_discriminatory_and_divisive.html. See also Tan Yi Liang, "Malaysian Bar: Kelantan Hudud is Unconstitutional and Discriminatory," The Star Online, March 20, 2015, http://www.thestar.com.my/News/Nation/2015/03/20/Malaysian-Bar-statement-onKelantan-hudud/.

${ }_{13}$ Thomas, "Is Malaysia an Islamic state?" xv. 
case. ${ }^{14}$ He further mentioned that careful analysis of Che Omar's case would reveal that the Supreme Court did not support such proposition. In a more controversial statement, the former Chief Justice of Malaysia, Ahmad Fairuz opined that Syariah is the "second most supreme" law and that "Islamic law takes precedence over civil legislation in Malaysia". He further mentioned that "just like laws that contradicted the Federal Constitution would be void, those that went against Islamic law's main sources, the Quran and Sunnah, would also be void". ${ }^{15}$

While the author celebrates freedom of expression as a guaranteed fundamental liberty under the MFC, meticulous study of the MFC is required to resolve these conflicting views, which precisely what the author intends to achieve through this paper.

\section{SECULARISM AND DOCTRINE OF BASIC STRUCTURE OF CONSTITUTION}

In this part, the author discusses two principles which are salient to the pro-secular group's contention that the MFC is a secular instrument making Malaysia a secular state.

\subsection{Secularism}

Some dictionaries simply define the term "secular" as "worldly" and "without spiritual element". According to Syed Muhammad Naquib Al-Attas, the term "secularisation" means:

The deliverance of man first from religious and then from metaphysical control over his reason and his language. It is the loosing of the world from religious and quasi-religious understanding of itself, the dispelling of all closed worldviews, the breaking of all supernatural myths and sacred symbols... the defatalisation of history, the discovery by man that he has been left with the world on his hands, and that he can no longer blame

\footnotetext{
"Malaysian Bar's Stand on Hudud Unconstitutional: Muslim Lawyers," Astro Awani, March 21, 2015, http://english. astroawani.com/malaysia-news/malaysian-bars-stand-hudud-unconstitutional-muslim-lawyers-13591.

15 Arfa Yunus, "Laws in Contradiction to Islamic Laws are void, says Former Chief Justice," The New Straits Times, March 25, 2017, https://www.nst.com.my/news/2017/03/224249/laws-contradiction-islamic-laws-are-void-saysformer-chief-justice.
} 
fortune or the furies for what he does with it...; man turning his attention away from worlds beyond and toward this world and this time. ${ }^{16}$

George Jacob Holyoake, a British writer who is said to be the person who coined the term "secularism" used it in about 1846 to describe "a form of opinion which concerns itself only with questions, the issues of which can be tested by the experience of this life. ${ }^{17}$ The original usage of the term "secularism" by him did not expressly reveal the concept of resistance to religion but rather, it suggested the idea of focusing on this present life rather than speculating about any other life or afterlife. Holyoake clarified his idea of secularism by saying:

Secularism is not an argument against Christianity, it is one independent of it. It does not question the pretensions of Christianity; it advances others. Secularism does not say there is no light or guidance elsewhere, but maintains that there is light and guidance in secular truth, whose conditions and sanctions exist independently, and act forever. Secular knowledge is manifestly that kind of knowledge which is founded in this life, which relates to the conduct of this life, conduces to the welfare of this life, and is capable of being tested by the experience of this life. ${ }^{18}$

From the above excerpt, secularism is not intended to challenge the truth or credibility of religion but rather it is independent from any discussion about religion. It promotes accentuation to the material and upon this world rather than the immaterial, spiritual or any other world. The concept was developed as a non-religious philosophy intended to stress upon the welfare and concerns of humanity in present life, not the potential needs and concerns related to any probable afterlife.

The pro-secular group in Malaysia, while arguing that the MFC is secular, did not properly and comprehensively define what they mean by the term "secular". While different scholars have offered different perspectives, based on the author's reading, the pro-secular group in Malaysia is referring to

16 Syed Muhammad Naquib Al-Attas, Islam, Secularism and Philosophy of the Future (London: Mansell Publishing Limited, 1985), 14.

${ }_{17}$ "Secularism," New Advent, accessed April 21, 2019, http://www.newadvent.org/cathen/13676a.htm.

18 lbid. 
total separation between state and religion, and neutrality in the matters of religion. This concept can be traced back to Thomas Jefferson's letter to Danbury Baptist Association in 1802 where he justified the reason as to why he would not proclaim national days of fasting and thanksgiving, as done by his predecessor, George Washington and John Adams. In the letter, the Third President of the United States stated:

Believing with you that religion is a matter which lies solely between man and his god, that he owes account to none other for his faith or his worship, that the legitimate powers of government reach actions only, and not opinions, I contemplate with sovereign reverence that act of the whole American people which declared that their legislature should make no law respecting an establishment of religion, or prohibiting the free exercise thereof, thus building a wall of separation between church and state. Adhering to this expression of the supreme will of the nation in behalf of the rights of conscience, I shall see with sincere satisfaction the progress of those sentiments which tend to restore to man all his natural rights, convinced he has no natural right in opposition to his social duties. ${ }^{19}$

In essence, secularism in the context of a state refers the principle of separation between government institutions and religious institution, preventing religion precepts from influencing the way through which a state is run by the politicians and preventing politicians from intervening the manners through which religion is administered by religious institutions.

The expression of "a wall of separation between church and state" does not mean mere separation but strict and total separation. This is evidenced from the words of the First Amendment to the US Constitution which provides that "Congress shall make no law respecting an establishment of religion, or prohibiting the free exercise thereof" leaving no room for religion in the governance of the state. In this respect, Justice Black in Everson v. Board of Education ${ }^{20}$ mentioned:

The "establishment of religion" clause of the First Amendment means at least this: Neither a state nor the Federal Government can set up a

\footnotetext{
19 "Jefferson's Wall of Separation Letter," Constitution Society, accessed April 21, 2019, http://www.constitution. org/tj/sep_church_state.htm.

20 Everson v. Board of Education 330 U.S. 1 (1947).
} 
church. Neither can pass laws which aid one religion, aid all religions, or prefer one religion to another ... in the words of Jefferson, the [First Amendment] clause against establishment of religion by law was intended to erect 'a wall of separation between church and State' ... That wall must be kept high and impregnable. We could not approve the slightest breach.

Secularism is therefore, not merely independent from religious doctrine and influence but also prohibition of subsequent importation or incorporation of religious element in the name of maintaining the strict wall of separation.

This is the concept referred at least by Karpal Singh ${ }^{21}$ and Steven Thiru, ${ }^{22}$ based on the fact that they argued the adoption of religious laws offends the purported secular nature of Malaysia. Civic group Bebas member, Azrul Mohd Khalib explained the perspective of the pro-secular group through the following words:

Secularism does not mean atheism. A secular state is a state that purports to be neutral in the matters of religion and it supports neither religion nor irreligion. When we look at the nature of a secular state and the relationship between the state and religion, what we are talking about is the separation of the state and religion...

\subsection{Doctrine of Basic Structure of Constitution}

It is a constitutional law doctrine founded by the Supreme Court of India which epitomises the idea that a constitution contains fundamental features which are so important and unamendable. The abrogation of any such features would result in complete obliteration of the existing constitution. The earliest discussion on the doctrine was in Sajjan Singh v State of Rajasthan ${ }^{23}$ where Justice J.R. Mudholkar in his dissenting judgment suggested:

The Constituent Assembly which was the repository of sovereignty could well have created a sovereign Parliament on the British model. But instead it enacted a written Constitution,... Above all, it formulated a solemn and dignified preamble which appears to be an epitome of

\footnotetext{
"Hudud Law Incompatible with Secular State, says Karpal".

"Hudud is Unconstitutional, Discriminatory and Divisive".

Sajjan Singh v State of Rajasthan 1965 AIR 845, 1965 SCR (1) 933.
} 
the basic features of the Constitution. Can it not be said that these are indicate of the intention of the Constituent Assembly to give a permanency to the basic features of the Constitution? It is also a matter for consideration whether making a change in a basic feature of the Constitution can be regarded merely as an amendment or would it be, in effect, rewriting a part of the Constitution; and if the latter, would it be within the purview of Art. 368 ?

...The Constitution indicates three modes of amendments and assuming that the provisions of Art. 368 confer power on Parliament to amend the Constitution, it will still have to be considered whether as long as the preamble stands unmended, that power can be exercised with respect to any of the basic features of the Constitution.

In the above excerpt, the learned judge was proposing that there should be limit to the parliament's power to amend the constitution so as to prevent it from "rewriting" the constitution as a result of abolishing its basic features.

In 1973, the idea was revisited in the landmark case of Kesavananda Bharati Sripadagalvaru and Others v. State of Kerala and Anr. ${ }^{24}$ where Justice J.R. Mudholkar's view was accepted through a narrow 7-6 verdict. The Indian apex court overruled its decision in Shankari Prasad v Union of India ${ }^{25}$ (that parliament's power to amend constitution is unlimited) and held, as per the view of K.S. Hegde and A.K. Mukherjea, JJ.:

...the Parliament has no power to abrogate or emasculate the basic elements or fundamental features of the Constitution such as the sovereignty of India, the democratic character of our polity, the unity of the country, the essential features of the individual freedoms secured to the citizens.

In addition, H.R. Khanna J. proceeded to make the following remark:

We may now deal with the question as to what is the scope of the power of amendment under Article 368. This would depend upon the connotation of the word "amendment". Question has been posed during arguments as to whether the power to amend under the above article includes the power to completely abrogate the Constitution and replace

\footnotetext{
${ }_{24}$ Kesavananda Bharati Sripadagalvaru and Others. v. State of Kerala and Anr (1973) 4 SCC 225.

25 Shankari Prasad v. Union of India AIR 1951 SC 458.
} 
it by an entirely new Constitution. The answer to the above question, in my opinion, should be in the negative. I am further of the opinion that amendment of the Constitution necessarily contemplates that the Constitution has not to be abrogated but only changes have to be made in it. The word "amendment" postulates that the old Constitution survives without loss of its identity despite the change and continues even though it has been subjected to alterations. As a result of the amendment, the old Constitution cannot be destroyed and done away with; it is retained though in the amended form. What then is meant by the retention of the old Constitution? It means the retention of the basic structure or framework of the old Constitution. A mere retention of some provisions of the old Constitution even though the basic structure or framework of the Constitution has been destroyed would not amount to the retention of the old Constitution. Although it is permissible under the power of amendment to effect changes, "howsoever important, and to adapt the system to the requirements of changing conditions, it is not permissible to touch the foundation or to alter the basic institutional pattern. The words "amendment of the Constitution" with all their wide sweep and amplitude cannot have the effect of destroying or abrogating the basic structure or framework of the Constitution. It would not be competent under the garb of amendment, for instance, to change the democratic government into dictatorship or hereditary monarchy nor would it be permissible to abolish the Lok Sabha and the Rajya Sabha. The secular character of the state according to which the state shall not discriminate against any citizen on the ground of religion only cannot likewise be done away with. Provision regarding the amendment of the Constitution does not furnish a pretence for subverting the structure of the Constitution nor can Article 368 be so construed as to embody the death wish of the Constitution or provide sanction for what may perhaps be called its lawful harakiri. Such subversion or destruction cannot be described to be amendment of the Constitution as contemplated by Article 368 .

In summary, the doctrine refers to the foundational features to the constitution which if amended, will have the effect of rewriting the constitution, altering the basic institutional pattern and "destroy" the existing constitution.

\subsection{Doctrine of Basic Structure in Malaysia}

The apex court has given two conflicting views on whether Malaysia subscribes to the Doctrine. First, the former Federal Court in Loh Kooi 
Choon v Government of Malaysia ${ }^{26}$ decided the Doctrine is not applicable. ${ }^{27}$ Wan Suleiman FJ stated:

The restriction upon the amending power of the Indian Parliament, according to this view arises from what is contained in the Preamble to the Indian Constitution...

The power to amend would not, in this country, be restricted by anything set out in a Preamble for there is no Preamble to our Constitution. It seems to me to be clear that if there is to be any restriction to the right to amend any of the fundamental rights set out in Part II, such restriction would have been set out in one of the various clauses of Article 159 itself.

Secondly, the present apex court in Sivarasa Rasiah v Badan Peguam Malaysia \& Another ${ }^{28}$ stated:

Further, it is clear from the way in which the Federal Constitution is constructed there are certain features that constitute its basic fabric. Unless sanctioned by the Constitution itself, any statute (including one amending the Constitution) that offends the basic structure may be struck down as unconstitutional. Whether a particular feature is part of the basic structure must be worked out on a case by case basis. Suffice to say that the rights guaranteed by Part II which are enforceable in the courts form part of the basic structure of the Federal Constitution.

The two conflicting views however, has been put to rest by latest pronouncement by the Federal Court in two latest cases of Semenyih Jaya Sdn Bhd v Pentadbir Tanah Daerah Hulu Langat and another case ${ }^{29}$ and Indira Gandhi a/p Mutho v Pengarah Jabatan Agama Islam Perak \& Others and other appeals ${ }^{30}$ which decided that the Doctrine is applicable in Malaysia.

However, the author wishes to highlight several noteworthy observations from the position taken by the apex court. Firstly, the notion of democratic state profoundly refers to a state governed by the majority will of the people. It is the majority will that first established the constitution and hence,

\footnotetext{
Loh Kooi Choon v. Government of Malaysia [1977] 2 MLJ 187.

Phang Chin Hock v Public Prosecutor [1980] 1 MLJ 70.

Sivarasa Rasiah v. Badan Peguam Malaysia \& Another [2010] 2 MLJ 333.

[2017] 3 MLJ 561.

[2018] 1 MLJ 545 .
} 
there should not be an impediment to the majority will to subsequently amend it. Otherwise, the impediment would undermine the fundamental of democracy. As majority will is reflected by majority vote in the parliament, to implement the doctrine which limits the parliament's power to amend the constitution is clearly inconsistent with the notion of democracy itself.

Secondly, while the Federal Court in Semenyih Jaya's case stated that the decision in Loh Kooi Choon was superseded in Sivarasa's case, no definite word used by the Federal Court in Sivarasa's case pointed that the Malaysian Parliament's power to amend the MFC is limited by the doctrine. The closest words are "Unless sanctioned by the Constitution itself, any statute (including one amending the Constitution) that offends the basic structure may be struck down as unconstitutional." In this regards, the words "unless sanctioned by the Constitution itself" creates ambiguity in the proposition that the doctrine applies because MFC in Article 159 clearly sanctions the parliament's power to amend the MFC.

Thirdly, the rationale given in Loh Kooi Choon's case that the doctrine is not applicable because it derives from the Preamble to the Indian Constitution whereas the MFC does not have preamble was not rebutted in Sivarasa's case. Fourthly, the argument posed by the Federal Court in Sivarasa's case that Vacher's case should not be followed by the Malaysian court because the UK embraces the Parliamentary Supremacy Doctrine is not a strong argument. This is because the MFC itself vests the parliament with the power to amend the constitution and hence, any amendment made by the parliament to the constitution is in no way prejudice the supremacy of the MFC or implies that Malaysia adopted the Parliamentary Supremacy Doctrine.

In any way, by virtue of stare decisis (judicial precedent) principle, we stand guided by the Federal Court's pronouncement in Semenyih Jaya's and Indira Gandhi's cases. 


\section{THE POSITION OF RELIGION IN THE MALAYSIAN FEDERAL CONSTITUTION}

It is an established principle of constitutional construction that no one provision of the MFC can be considered in isolation but instead, a particular provision in question must be brought into view together with all other provisions bearing upon that particular subject. This principle has been reiterated again and again by the Federal Court in many cases including in Danaharta Urus Sdn Bhd v Kekatong Sdn Bhd \& Another ${ }^{31}$ and ZI Publications v Kerajaan Negeri Selangor. ${ }^{32}$ Thus, in considering whether secularism is a basic structure of the MFC or otherwise, it is incumbent to consider the constitutional framework as a whole and not by reading a particular provision in isolation. With this principle in mind, the author will now analyse the position of Islam and secularism in the MFC and determine whether it is a secular instrument creating a secular state or a religious document establishing a theocratic state. For that, the author will provide five main arguments.

Firstly, argument on preparatory works of the MFC. There is no doubt that the preparatory works of the MFC contained clear records that Persekutuan Tanah Melayu (the predecessor of Malaysia) was intended to be a secular state as evidenced in the following excerpts on the issue of state religion:

(a) the Alliance Memorandum submitted by the Parti Perikatan (Alliance Party) to the Reid Commission stated:

The religion of Malaysia shall be Islam. The observance of this principle shall not impose any disability on non-Muslim nationals professing and practising their own religion, and shall not imply that the State is not a secular State. 33

(b) the Reid Commission Report published in February 1957 stated:

169. We have considered the question whether there should be any statement in the Constitution to the effect that Islam should be the State religion.

\footnotetext{
Danaharta Urus Sdn Bhd v. Kekatong Sdn Bhd \& Another [2004] 2 MLJ 257.

32 ZI Publications Sdn Bhd and Another v. Kerajaan Negeri Selangor [2016] 1 MLJ 153.

33 Thomas, "Is Malaysia an Islamic state?" xv.
} 
There was universal agreement that if any such provision were inserted it must be made clear that it would not in any way affect the civil rights of non-Muslims - 'the religion of Malaysia shall be Islam. The observance of this principle shall not impose any disability on non-Muslim nationals professing and practising their own religion and shall not imply that the State is not a secular State'. There is nothing in the draft Constitution to affect the continuance of the present position in the States with regard to recognition of Islam or to prevent the recognition of Islam in the Federation by legislation or otherwise in any respect which does not prejudice the civil rights of individual non-Muslims. The majority of us think that it is best to leave the matter on this basis, looking to the fact that Counsel for the Rulers said to us - 'It is Their Highnesses' considered view that it would not be desirable to insert some declaration such as has been suggested that the Muslim Faith or Islamic Faith be the established religion of the Federation. Their Highnesses are not in favour of such declaration being inserted and that is a matter of specific instruction in which I myself have played very little part.' Mr Justice Abdul Hamid is of opinion that a declaration should be inserted in the Constitution as suggested by the Alliance and his views are set out in his note appended to this Report. ${ }^{34}$

(c) the Alliance response to the issue raised in the Reid Commission Report with regard to the issue of state religion:

The UMNO leaders contended that provision for an official religion would have an important psychological impact on the Malays. But in deference to the objections of the Rulers and the concerns of non-Muslims, the Alliance agreed that the new article should include two provisos: first, that it would not affect the position of the Rulers as head of religion in their respective States; and second, that the practice and propagation of other religions in the Federation would be assured under the Constitution. The MCA and MIC representatives did not raise any objections to the new article, despite protests

34 Abdul Aziz Bari and Farid Sufian Shuaib, Constitution of Malaysian: Text and Commentary, $2^{\text {nd }}$ edition, (Selangor: Pearson, 2006), 6. See also Teoh Eng Huat v Kadhi, Pasir Mas \& Another [1990] 2 MLJ 300. 
by many non-Muslim organizations, as they were given to understand by their UMNO colleagues that it was intended to have symbolic significance rather than practical effect, and that the civil rights of the non-Muslims would not be affected. Mac Gillivray personally felt that such a provision would be advantageous because the Yang di-Pertuan Agong could at the same time become the head of the faith in the Settlements of Penang and Malacca. The Colonial Office, while apprehensive at first, did not object after being assured by the Alliance leaders during the London Conference in May 1957 that they 'had no intention of creating a Muslim theocracy and that Malaya would be a secular State'.35

(d) the Federation of Malaya Constitutional Proposals 1957, also known as the White Paper, stated:

57. There has been included in the proposed Federal Constitution a declaration that Islam is the religion of the Federation. This will in no way affect the present position of the Federation as a secular State, and every person will have the right to profess and practice his own religion and the right to propagate his religion, though this last right is subject to any restrictions imposed by State law relating to the propagation of any religious doctrine or belief among persons professing the Muslim religion. ${ }^{36}$

(e) Lennox Boyd, the Colonial Secretary's letter to Lord Reid on 31 May 1957 offering tribute and gratitude to the work done by the Reid Commission after the Constitutional Bill was debated in the British Parliament and in the Federal Legislative Council in Kuala Lumpur and subsequently passed without amendment stated:

The Rulers, as you know, changed their tune about Islam and they and the Government presented a united front in favour of making Islam a state religion even though Malaya is to be a secular state. ${ }^{37}$

\footnotetext{
35 JM Fernando, The Making of the Malayan Constitution, (Malaysia: Malaysian Branch of the Royal Asiatic Society, 2002), 162-163.

36 Abdul Aziz and Farid, Constitution of Malaysian: Text and Commentary, 7.

37 Thomas, "Is Malaysia an Islamic state?" xv.
} 
(f) Report of the Commission of Enquiry, North Borneo and Sarawak, 1962 (also known as the Cobbold Commission)

We think that all Muslim communities would become a provision that Islam should be the national religion of the Federation. Amongst the nonMuslim who appeared before us there was a substantial number who would not object to the present practice in the Federation of Malaya, as they are satisfied with the provisions for fundamental liberties and freedom of religion in the Malayan Constitution. There were however, a number of nonMuslims who were most anxious that there should be no national religion for the Federation; a great many of them, however, would be prepared to consider that Islam might be made the national religion provided that it should not be the religion of their particular State.

Taking these points fully into consideration, we are agreed that Islam should be the national religion for the Federation. We are satisfied that the proposal in no way jeopardizes freedom of religion in the Federation, which in effect would be secular. ${ }^{38}$

Based on the above records, pro-secular group argued that framers of the MFC intended it to be secular.

Despite the repeated emphasise in the preparatory works that the insertion of provision on state religion should not affect the secular nature of Persekutuan Tanah Melayu, nowhere in the MFC states that it is a secular document or it intends to establish a secular state. This is unlike France, Turkey and India which constitutions, in no uncertain term, declare the states as secular states. Instead, the total opposite happened whereby the Merdeka Constitution contains many provisions on matters relating to Islam namely:

(a) Article 3: Islam as religion of the Federation and the YDPA's function as the head of religion of Islam for the Federation, states without rulers and federal territories;

${ }_{38}$ "Malaysia Social Contract (Part 2): Excerpts from Historical Documents," Krisis \& Praxis, accessed April 21, 2019, https://www.krisispraxis.com/archives/2007/05/social-contract-part-2-excerpts-from-historical-documents/. 
(b) Article 11(4): Power of the parliament and state legislature to make law to control or restrict the propagation of any religious doctrine or belief among Muslims;

(c) Article 12(2): Federal law or state law may establish, maintain or assist Islamic institutions or provide or assist in providing instruction in Islam and incur necessary expenses for that purpose;

(d) Article 37(1) read together with the Fourth Schedule: The name of Allah as part of the oath of office of the YDPA as the head of state as well as the oath of the Timbalan YDPA.

(e) Article 38: Function of the Conference of Rulers on agreeing or disagreeing to the extension of any religious acts, observances or ceremonies to the Federation; and

(f) Article 74(2) read together with Second List of the Ninth Schedule (State List): Power of the state to legislate laws on Islamic matters including marriage, inheritance, guardianship, waqaf, zakat, fitrah, baitulmal and creation and punishment of offences by Muslims against precepts of Islam.

In the author's view, there cannot be a stronger proof than this to support that the MFC is not a secular document. This is so simply because if a provision establishing a secular state is inserted, no way would the Malays who were the majority citizens of Tanah Melayu would agree to such constitution and no way would the Malay Rulers assent to sign the agreement for the establishment of Persekutuan Tanah Melayu given that Islam was the backbone of the Malay community during that era. Had it not because of colognisation which introduced foreign law into Tanah Melayu, Islam would continue to be the law of the land because such was the position as acknowledged in Shaik Abdul Latif v Shaik Elias Bux ${ }^{39}$ and Ramah v Laton ${ }^{40}$ and it was never the intention of the Malays to adopt a different legal system.

The initial sentiment of the Malay Rulers as recorded in the Reid Commission Report was not because of their objection towards making Persekutuan Tanah Melayu an Islamic state or because of their support for the establishment of a 
secular state. It was rather due to their intention to ensure power on matters relation to Islam remains with the Malay Rulers and also their concern that if a provision on state religion is inserted, their exclusive powers which were already limited would be further depleted. The Tujuh Wasiat Raja-raja Melayu which contains declaration by the Malay Rulers, when they signed the agreement for the establishment of Persekutuan Tanah Melayu on 5 August 1957, that Islam shall be the religion of the Federation ${ }^{41}$ supports this argument.

However, the pertinent question now is how to reconcile between the preparatory works and the provisions in the MFC which appear contradictory? The Federal Court ruled that, "A constitution must be interpreted in light of its historical and philosophical context". In Indira Gandhi's case, the apex court quoted with approval, the words of the Supreme Court of Canada in Reference re Senate Reform: "The rules of constitutional interpretation require that constitutional documents be interpreted in a broad and purposive manner and placed in their proper linguistic, philosophic, and historical contexts..."42

In view of the above rules of interpretation, the MFC cannot be interpreted strictly and restrictively within the constraint of its preparatory works which in effect will render the MFC as an obsolete document incapable of adapting to historical, social, cultural and developing environment surrounding it. Further, religion especially Islam has always been an important component of the Malay society before Merdeka and even now. These facts cannot be neglected in understanding the MFC as the document that governs the Malaysian society.

Based on the contents of the Merdeka Constitution and the earlier explained concept of secularism, the essence of secularism i.e. strict wall of separation between the state and religion does not exist in the MFC. In this regard, the author argues that as far as rules of interpretation is concerned, if the literal construction of a provision is inconsistent with its preparatory works, then the

\footnotetext{
41 "Tujuh wasiat Raja-Raja Melayu, [The Seven Testaments of King of Malay], " Malaysia kini, accessed April 21, 2019, https://www.malaysiakini.com/news/110050. See also Zuliza Mohd Kusrin, Zaini Nasohah, Mohd al-Adib Samuri and Mat Noor Mat Zain, "Legal Provisions and Restrictions on the Propagation of Non-Islamic Religions among Muslims in Malaysia," Kajian Malaysia 31, no.2 (2013): 1-18.

${ }^{42}$ [2014] 1 SCR 704; (2014) SCC 32 at paragraphs 25-26.
} 
literal interpretation of the provision must be given precedence. This is because logic tells us that the obvious discrepancy between the literal wordings and the preparatory works must mean either the drafter intended to totally deviate from the preparatory works or the preparatory works should be read in the light of the actual provision and not vice versa because preparatory works are not binding like the actual provisions.

If the case is the former, the preparatory works should be ignored in totality because reliance on them would deviate from the real meaning of the actual provisions. However, since there is no proof that the former is the actual case, the author is of the view that the latter must be the right approach to be adopted i.e. to understand the preparatory works in the light of the actual provision so as to avoid the provision from losing its authoritative value to mere preparatory works. Looking to both the provision and preparatory works side by side, the author argues what is meant by "secular state" in the preparatory works is not equivalent to secularism that have been discussed earlier but a loose usage of the word to merely reflect that Persekutuan Tanah Melayu is not a pure theocratic state. ${ }^{43}$ The constitution neither mandates total separation nor prohibits subsequent adoption of religious element into the state. This understanding is supported by the High Court's comments in Lina Joy v. Majlis Agama Islam Wilayah \& Another ${ }^{44}$ on the Supreme Court's decision in Che Omar's case where it states:

The constitution of this hybrid model accord official or preferential status to Islam but does not create a theocratic state like Saudi Arabia or Iran. Contrary to the plaintiff's assertion, the subject and purpose of art 3(1) is not merely 'to fix' the official religion of a nation. The case of Che Omar bin Che Soh v Public Prosecutor [1988] 2 MLJ 55 did not decide on art 3(1), that is, the meaning of Islam as the Religion of the Federation (see Sheridan - The Religion of the Federation[1988] 2 MLJ xiii. Article 3(1) has a far wider and meaningful purpose than a mere fixation of the official religion.

\footnotetext{
43 "Historian Explains Why Malaysia is Neither Secular Nor Islamic," FMT, accessed April 21, 2019, https://www. freemalaysiatoday.com/category/nation/2017/og/22/historian-explains-why-malaysia-is-neither-secular-nor-islamic/.

44 Lina Joy v. Majlis Agama Islam Wilayah \& Another [2004] 2 MLJ 119.
} 
To hold an extreme opposite view that secularism is a basic structure of the MFC despite its obvious contents which give importance to Islam from the aspect of appointment of head of state to the extent of recognising Islam as a source of law is logically, factually and legally unacceptable.

Secondly, argument the Supreme Court's decision in Che Omar's case. Contrary to the pro-secular group's contention, careful reading of the Supreme Court's judgment revealed that it did not declare the MFC as a secular constitution but merely stating that the prevailing law in 1988 adopted by Malaysia was secular law (which is not accurate since drug trafficking and possession of firearm offences in Islam may fall within the scope of ta'zir crime which according to some muslim jurists, may be punishable with capital punishment) and such is allowed by the MFC.

The author argues that there is a significant difference between the MFC is secular and the law adopted by Malaysia is secular. In the latter case, it does not mean the MFC is secular but rather religion-neutral and receptive to any law be it religious or secular for as long as it undergoes proper procedural processes required by the MFC. The Supreme Court's argument that there is no provision which nullifies law that is contrary to Islam does not prove that the MFC is secular but rather proves that it is religion-neutral because it neither nullifies law related to religion nor prohibit the legislature from making law on religious matters. 45

The Lord President in the same case further argued when British ascribed sovereignty to the rulers (i.e. to a human being), the divine source of legal validity (which were the original system prior to colonial period) was severed and thus the British turned the system into a secular institution. In this regard, the author regrets the Lord President failed to appreciate the importance to segregate between what the British intended Persekutuan Tanah Melayu to be and what the people of the Federation wanted it to be. The British intended the

45 Mohamed Azam, "Is Malaysia a Secular State?" New Straits Times, December 28, 2019, https://www.nst.com. my/opinion/columnists/2018/12/444567/malaysia-secular-state. See also Kow Gah Chie, "Law Expert: Malaysia Neither Secular nor Islamic State," Malaysiakini, January 25, 2019. https://www.malaysiakini.com/news/461745. 
Federation to be a secular state governed the Malayan Union which was rejected by the people. Instead, the Reid Commission was formed to collate collective views of the people on the contents of the constitution that would become the supreme law of the land. Hence, the MFC is the product of people's wills, neither the British's will not the Reid Commission's will. Thus the author argues this as a clear evidence that the MFC should not be interpreted according to what the British wanted the Federation to be. Instead, the MFC is a document that comprises, among others, the history, civilization and culture of the people which include Islam as a salient component. The independence of Persekutuan Tanah Melayu would be meaningless if the British will is still dominant in the interpretation of the MFC.

In Dato Menteri Othman Bin Baginda \& Another v. Dato Ombi Syed Alwi Bin Syed Idrus, ${ }^{46}$ the Federal Court stated:

In interpreting a constitution two points must be borne in mind. First, judicial precedent plays a lesser part than is normal in matters of ordinary statutory interpretation. Secondly, a constitution, being a living piece of legislation, its provisions must be construed broadly and not in a pedantic way - "with less rigidity and more generosity than other Acts" (see Minister of Home Affairs v Fisher [1979] 3 All ER 21. A constitution is sui generis, calling for its own principles of interpretation, suitable to its character, but without necessarily accepting the ordinary rules and presumptions of statutory interpretation. As stated in the judgment of Lord Wilberforce in that case: "A constitution is a legal instrument given rise, amongst other things, to individual rights capable of enforcement in a court of law. Respect must be paid to the language which has been used and to the traditions and usages which have given meaning to that language. It is quite consistent with this, and with the recognition that rules of interpretation may apply, to take as a point of departure for the process of interpretation a recognition of the character and origin of the instrument, and to be guided by the principle of giving full recognition and effect to those fundamental rights and freedoms." The principle of interpreting constitutions "with less rigidity and more generosity" was again applied by the Privy Council in Attorney-General of St Christopher, Nevis and Anguilla v Reynolds [1979] 3 All ER 129, 136.

${ }_{46}$ Dato Menteri Othman Bin Baginda \& Another v. Dato Ombi Syed Alwi Bin Syed Idrus [1981] 1 MLJ 29. 
Having regards to the above stated principle of constitutional interpretation, the author submits that the Lord President's contention that the British turned the system into a secular institution cannot be sustained as an argument to conclude Malaysia as a secular state.

Thirdly, the pro-secular group asserts that the Supreme Court in Che Omar's case decided the scope of Islam in Article 3 is limited to rituals and ceremonies only. It is the author's view that meticulous appraisal of the Supreme Court's judgment reveals that although the Supreme Court asked the question, whether "the religion of Islam in the context means only such acts as relate to rituals and ceremonies", it did not give a conclusive answer to the question. As commented by the High Court in Lina Joy's case, the Supreme Court in Che Omar's case did not decide on Article 3(1) on the meaning of Islam as the Religion of the Federation but rather whether death penalty for drug trafficking and possession of firearm offences was unconstitutional. As such, the author further argues that it is misleading to claim the Supreme Court answered the question in the affirmative since the Supreme Court mentioned, "Islamic law was rendered isolated in a narrow confinement of the law of marriage, divorce, and inheritance only" whereas marriage, divorce and inheritance are not matters of mere rituals and ceremonials but involve legal rights and responsibilities. Besides, the author agrees with the High Court in:

(a) Meor Atiqulrahman's case which stated that Article 3 has the effect of uplifting the status of Islam above other religions; and

(b) Lina Joy's case which stated, "Article 3(1) has a far wider and meaningful purpose than a mere fixation of the official religion".

Fourthly, cases like Sulaiman bin Takrib v. Kerajaan Negeri Terengganu ${ }^{47}$, Fathul Bari v. Majlis Agama Islam Negeri Sembilan ${ }^{48}$, ZI Publication's case and Muhamad Juzaili v. State Government of Negeri Sembilan ${ }^{49}$ show there were many attempts to strike down state's legislations on offences against the precepts of Islam on the ground of constitutionality. For instance, the Court

Sulaiman bin Takrib v. Kerajaan Negeri Terengganu [2009] 2 CLJ 54.

8 Muhamad Juzaili Bin Mohd Khamis \& Others v. State Government of Negeri Sembilan \& Others [2015] 3 MLJ 513.

49 Muhamad Juzaili Bin Mohd Khamis \& Others v. State Government of Negeri Sembilan \& Others [2015] 3 MLJ 513. 
of Appeal Juzaili's case had ignored the Four Walls Doctrine ${ }^{50}$ and was very liberal in interpreting the MFC by adopting, among others, interpretation from states that clearly upholds secularism (India and USA) and by disregarding the position of Islam in the constitution and the SLA's constitutional right to enact laws on religious matters. Nevertheless, the Federal Court in all the above cases upheld the constitutionality of the state legislations.

In ZI Publications' case, the Federal Court remarked that there can be no doubt the MFC allows SLA to enact laws against the precepts of Islam. In Fathul Bari's case, the Federal court stated the SLA had acted within its legislative power in enacting law with the purpose to protect the integrity of the aqidah (belief), syariah (law) and akhlak (morality) of muslims which constituted the precepts of Islam. In Sulaiman bin Takrib's case, the Federal Court explained the SLA's power to enact law on the creation and punishment of offences under Item 1 of the State List subject to four conditions:

(a) it is confined to persons professing the religion of Islam;

(b) it is against the precepts of Islam;

(c) it is not with regard to matters included in the Federal List; and

(d) it is within the limit set by Section 2 of the Syariah Courts (Criminal Jurisdiction) Act 1965 .

Accordingly, the author argues that it is irrational to insist that the MFC is secular when the Federal Court had in many occasions decided the MFC empowers the SLA to enact laws on the creation and punishment of offences against the precepts of Islam.

Fifthly, the author had earlier ventured into the doctrine of basic structure of constitution. In this context, the author argues that it is illogical to say in the first place that something which is so fundamental to the constitution is being neglected from expression especially when it has been repeated numerous times in the preparatory works. This fact can be implied to mean secularism was not

\footnotetext{
5o The Court in The Government of The State of Kelantan v The Government of The Federation of Malaya and Tunku Abdul Rahman Putra Al-Haj [1963] 1 MLJ 355 stated "The second consideration is that the Constitution is primarily to be interpreted within its own four walls and not in the light of analogies drawn from other countries such as Great Britain, the United States of America or Australia."
} 
intended to be inserted in the MFC. In Titular Roman Catholic Archbishop's case, Apandi Ali JCA, while delivering the Court of Appeal's judgment, states:

It is my observation that the words 'in peace and harmony' in art 3(1) has a historical background and dimension, to the effect that those words are not without significance. The article places the religion of Islam at par with the other basic structures of the Constitution, as it is the third in the order of precedence of the articles that were within the confines of Part I of the Constitution. It is pertinent to note that the fundamental liberties articles were grouped together subsequently under Part II of the Constitution.

From the above, the author further argues that secularism does not qualify as a basic structure of the MFC because it has been deliberately neglected from being mentioned in the MFC and instead, it is more apparent that Islam is intended to be a basic feature of the MFC due to its importance and frequent repetition in the MFC on various subjects.

Nonetheless, the understanding of Article 3(1) as suggested by Ahmad Fairuz that Syariah is the "second most supreme" law of Malaysia is also not tenable ${ }^{51}$. With respect, the author finds this proposition is neither supported by constitutional provision nor case law. In fact, Article 3(4) of the MFC states, "Nothing in this Article derogates from any other provision of this Constitution". This means that Article 3(1) must be read harmoniously with other provisions of the MFC including Article 162 which preserves pre-Merdeka laws notwithstanding it is secular as well as Articles 73 and 74 on the legislative power of the legislature regardless that the law passed by it is secular or religious.

\section{CONCLUSION}

There is no conclusive evidence to establish with certainty that secularism is a basic structure of the MFC. The pro-secular group heavily relied on the preparatory works of the MFC which no doubt mentioned that the insertion of Islam as a state's religion does not derogate from the secular nature of the Federation. They also referred to Che Omar's case which appears to support such

51 Shad Saleem Faruqi, "Constitution - the litmus test of validity," The Star Online, March 30, 2017, https://www. thestar.com.my/opinion/columnists/reflecting-on-the-law/2017/03/30/constitution-the-litmus-test-of-validity-theassertion-that-islamic-law-takes-precedence-over-civil/. 
proposition. However, it is important to note that Islam in the MFC does not only appear in Article 3 but in many other articles. In fact, Islam plays significant role in the Malaysian legal system be it from the aspect of appointment of head of state to the extent of serving as a source of law. With this important fact, the author argues that the term "secular" used in the preparatory works does not refer to "strict wall of separation between state and religion". Instead, the term has been loosely used to indicate that Malaysia, at the time of its establishment is not intended to be a pure theocratic state. This however, does not in any way preclude subsequent adoption of religious law by the legislature or even the subsequent shift into becoming a pure theocratic state.

Therefore, the author concludes that the MFC is not a secular document creating a secular state and despite giving special preference to Islam as the religion of the Federation, it is not a religious document establishing a pure theocratic state. The MFC is rather a religion-neutral document which is receptive to both religious, in particular Islamic and secular laws.

\section{BIBLIOGRAPHY}

Adil, Mohamed Azam Mohamed. "Is Malaysia a Secular State?" New Straits Times, December 28, 2019. https://www.nst.com.my/opinion/ columnists/2018/12/444567/malaysia-secular-state.

Al-Attas, Syed Muhammad Naquib. Islam, Secularism and Philosophy of the Future. London: Mansell Publishing Limited, 1985.

Astro Awani. "Malaysian Bar's Stand on Hudud Unconstitutional: Muslim Lawyers.” March 21, 2015. http://english.astroawani.com/malaysia-news/ malaysian-bars-stand-hudud-unconstitutional-muslim-lawyers-13591.

Azizan, Hariati. "Secular in Spirit." The Star Online, April 2, 2017. https://www. thestar.com.my/news/nation/2017/o4/o2/secular-in-spirit-we-need-to-lookat-our-shared-past-namely-the-founding-principle-of-the-country-an/.

Bari, Abdul Aziz. Malaysian Constitution: A Critical Introduction. Malaysia, Kuala Lumpur: The Other Press, 2008. 
Bari, Abdul Aziz \& Farid Sufian Shuaib. Constitution of Malaysia: Text and Commentary ( $2^{\text {nd }}$ edition). Malaysia, Selangor: Pearson, 2006.

Che Omar Bin Che Soh v Public Prosecutor [1988] 2 MLJ 55.

Chen, Lee Ban. "The Islamic State Debacle.” Malaysiakini, November 11, 2001. http://www.malaysiakini.com/columns/7017.

CNN.com. "Mahathir: Malaysia is 'Fundamentalist State." CNN.com/World. June 18, 2002. http://edition.cnn.com/2002/WORLD/asiapcf/southeast/o6/18/ malaysia.mahathir/.

Constitution Society. "Jefferson's Wall of Separation Letter." Accessed April 21, 2019. http://www.constitution.org/tj/sep_church_state.htm.

Danaharta Urus Sdn Bhd v. Kekatong Sdn Bhd \& Another [2004] 2 MLJ 257.

Dato Menteri Othman Bin Baginda \& Another v. Dato Ombi Syed Alwi Bin Syed Idrus [1981] 1 MLJ 29.

Everson v. Board of Education 330 U.S. 1 (1947).

Faruqi, Shad Saleem. "Constitution - the Litmus Test of Validity." The Star Online, March 30, 2017. https://www.thestar.com.my/opinion/columnists/ reflecting-on-the-law/2017/03/30/constitution-the-litmus-test-of-validity-theassertion-that-islamic-law-takes-precedence-over-civil/.

Fathul Bari bin Mat Jahya \& Another v. Majlis Agama Islam Negeri Sembilan \& Others [2012] 4 MLJ 281.

Fernando, JM. The Making of the Malayan Constitution. Malaysia, Kuala Lumpur: Malaysian Branch of the Royal Asiatic Society, 2002.

FMT. "Historian Explains Why Malaysia is Neither Secular Nor Islamic." FMT, accessed April 21, 2019. https://www.freemalaysiatoday.com/category/ nation/2017/09/22/historian-explains-why-malaysia-is-neither-secular-norislamic/.

Indira Gandhi a/p Mutho v. Pengarah Jabatan Agama Islam Perak \& Others and other appeals [2018] 1 MLJ 545. 
Kesavananda Bharati Sripadagalvaru and Others v. State of Kerala and Anr (1973) 4 SCC 225.

Kow Gah Chie. "Law Expert: Malaysia Neither Secular nor Islamic State." Malaysiakini, January 25, 2019. https://www.malaysiakini.com/news/461745.

Krisis \& Praxis. "Malaysia Social Contract (Part 2): Excerpts from Historical Documents." Accessed April 21, 2019. https://www.krisispraxis.com/ archives/2007/05/social-contract-part-2-excerpts-from-historical-documents/.

Limkitsiang.com. "DAP CEC will Consider Proposal to Take Mahathir to Court for His "929 Declaration" and His "617 Announcement" that Malaysia is an Islamic Fundamentalist State." Accessed April 21, 2019. http://www. limkitsiang.com/archive/2002/juno2/lks1658.htm.

Lina Joy v. Majlis Agama Islam Wilayah \& Another [2004] 2 MLJ 119.

Loh Kooi Choon v. Government of Malaysia [1977] 2 MLJ 187.

Malaysiakini. "Tujuh Wasiat Raja-Raja Melayu [The Seven Testaments of King of Malay]." Accessed April 21, 2019. https://www.malaysiakini.com/news/110050.

Menteri Dalam Negeri \& Others v. Titular Roman Catholic Archbishop of Kuala Lumpur [2013] 6 MLJ 468.

Meor Atiqulrahman Bin Ishak \& Others v. Fatimah Bte Sihi \& Others [200o] 5 MLJ 375.

Muhammad Hilman bin Idham \& Others v. Kerajaan Malaysia \& Others [2011] 6 MLJ 507.

Muhamad Juzaili Bin Mohd Khamis \& Others v. State Government of Negeri Sembilan \& Others [2015] 3 MLJ 513.

New Advent. "Secularism." Accessed April 21, 2019. http://www.newadvent.org/ cathen/13676a.htm.

Nik Noorhafizi bin Nik Ibrahim \& Others v. Public Prosecutor [2013] 6 MLJ 66o.

Phang Chin Hock v. Public Prosecutor [1980] 1 MLJ 70.

Ramah v Laton (1927) 6 F.M.S.L.R. 128. 
Sajjan Singh v. State of Rajasthan 1965 AIR 845, 1965 SCR (1) 933.

Semenyih Jaya Sdn Bhd v. Pentadbir Tanah Daerah Hulu Langat and another case [2017] 3 MLJ 561

Shaik Abdul Latif v. Shaik Elias Bux (1915) 1 F.M.S.L.R. 204.

Shankari Prasad v. Union of India AIR 1951 SC 458.

Sivarasa Rasiah v. Badan Peguam Malaysia \& Another [2010] 2 MLJ 333.

Stilt K. "Contextualizing Constitutional Islam: the Malaysian Experience." International Journal of Constitutional Law 13, no. 2 (2015): 407-433.

Sulaiman bin Takrib v Kerajaan Negeri Terengganu [2009] 2 CLJ 54.

Tan Yi Liang. "Malaysian Bar: Kelantan Hudud is Unconstitutional and Discriminatory.” The Star Online, March 20, 2015. http://www.thestar.com. my/News/Nation/2015/o3/20/Malaysian-Bar-statement-on-Kelantan-hudud/.

Teoh Eng Huat v. Kadhi, Pasir Mas \& Another [1990] 2 MLJ 300.

The Malaysian Bar. "Hudud is Unconstitutional, Discriminatory and Divisive." Accessed April 21, 2019. http://www.malaysianbar.org.my/press_statements/ press_release_\%7C_hudud_is_unconstitutional_discriminatory_and_divisive. html.

The Malaysian Bar. "MCCBCHST's Press Statement: Malaysia is Not an Islamic State.” Accessed April 21, 2019. http://www.malaysianbar.org.my/letters_ others/mccbchsts_press_statement_malaysia_is_not_an_islamic_state.html. The Malaysian Bar. "Preserving the Integrity of the Constitution." Accessed April 21, 2019. http://www.malaysianbar.org.my/speeches/preserving_the_ integrity_of_the_constitution.html.

The Rocket. "Hudud Law Incompatible with Secular State, Says Karpal." Accessed April 21, 2019. https://www.therocket.com.my/en/implementation-of-hududin-kelantan-is-ill-advised-says-karpal/.

Thomas, Tommy. "Is Malaysia an Islamic state?" Malayan Law Journal, no. 4 (2006): xV- xlvii. 
Yunus, Arfa. "Laws in Contradiction to Islamic Laws are Void, says Former Chief Justice." The New Straits Times, March 25, 2017. https://www.nst.com.my/ news/2017/03/224249/laws-contradiction-islamic-laws-are-void-says-formerchief-justice.

ZI Publications Sdn Bhd and Another v. Kerajaan Negeri Selangor [2016] 1 MLJ 153.

Zuliza Mohd Kusrin, Zaini Nasohah, Mohd al-Adib Samuri and Mat Noor Mat Zain. "Legal Provisions and Restrictions on the Propagation of Non-Islamic Religions among Muslims in Malaysia." Kajian Malaysia 31, no. 2, (2013), 1-18. 